Document downloaded from:

http://hdl.handle.net/10251/63048

This paper must be cited as:

Cortés Olmos, C.; Leiva Brondo, M.; Adalid Martinez, AM.; Cebolla Cornejo, J.; Nuez Viñals, F. (2011). Identification of organoleptic and functional quality profiles in Spanish traditional cultivars of tomato. 28th International Horticultural Congress on Science and Horticulture for People (IHC2010): 3rd International Symposium on Plant Genetic Resources. International Society for Horticultural Science (ISHS). doi:10.17660/ActaHortic.2011.918.62.

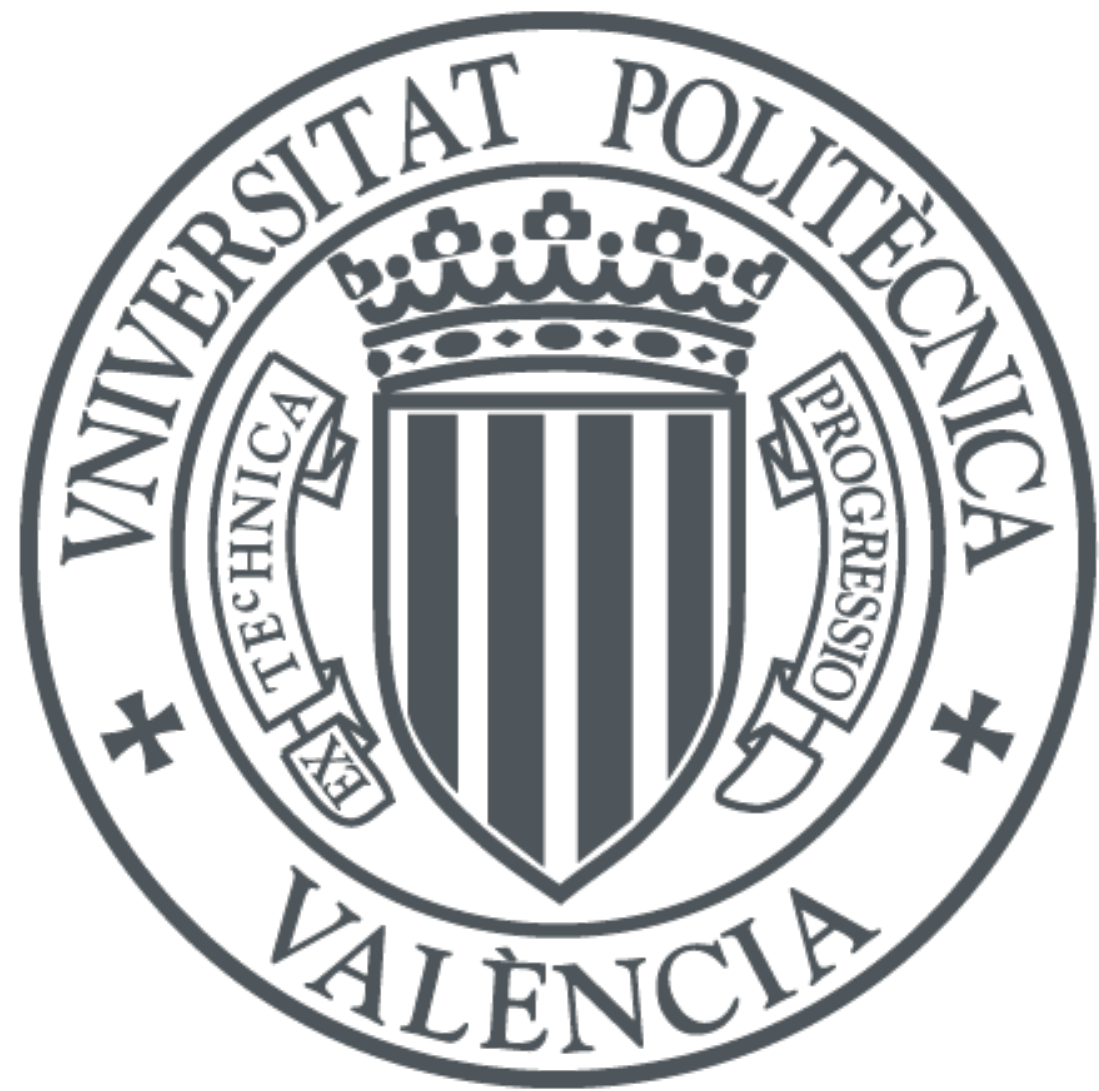

The final publication is available at

http://dx.doi.org/10.17660/ActaHortic.2011.918.62

Copyright International Society for Horticultural Science (ISHS)

Additional Information

The original publication is available at www.actahort.org 


\title{
Identification Organoleptic and Functional Quality Profiles in Spanish Traditional Varieties of Tomato
}

\author{
Cortés-Olmos, C., Leiva-Brondo, M., Adalid, A.M., Cebolla-Cornejo, J., Nuez, F.
}

Instituto Universitario de Conservación y Mejora de La Agrodiversidad Valenciana. Universidad Politécnica de Valencia. Cno. De Vera, s.n. 46022. Valencia. Spain

Keywords: genetic resources, diversity, lycopene, ascorbic acid, sugars, acids

\begin{abstract}
Despite the increasing importance of internal quality in breeding programmes and marketing of tomato, little information is available regarding organoleptic and functional profiles of traditional varieties of renowned quality. This is the objective of this work, consisting in the evaluation of internal quality of 51 traditional tomato accessions representative of the Spanish variability. Contents of total soluble solids, oxalic, malic, citric and glutamic acids, fructose, glucose and sucrose, vitamin $C$ and lycopene were determined, obtaining the respective organoleptic and functional profiles. These profiles will be very valuable to establish breeding objectives, as these varieties are considerably appreciated by consumers, who are willing to pay higher prices for them. A considerably high level of variability has been found in the profiles obtained and no clear groups could be identified considering fruit morphology or local name. Variability was higher in traits affecting functional quality (coefficients of variation of $51.2 \%$ for vitamin $C$ and $\mathbf{7 4 . 6 \%}$ for lycopene content) than those affecting organoleptic quality (coefficients of variation ranging from $18 \%$ for total soluble contents to $38.8 \%$ for glutamic acid). Additionally, several accessions could be selected for their higher individual contents for further studies of internal quality. It is the case of accessions CDP8102 and CDP3547 for their high malic content, accession CDP6315 for high fructose and glucose contents, accession CDP1523 for its lycopene content and accessions CDP2226 and CDP336 for vitamin C content. Considering previous correlations among individual contents and consumer preference accessions CDP7554, CDP2666 and CDP3547 should be further evaluated for their overall flavour quality.
\end{abstract}

\section{INTRODUCTION}

For a long time, the quality of vegetables has been based only on their external appearance. This limited definition of quality was due to the marketing strategies of large distribution firms. Such strategies were focused on the visual impact of products. Nowadays, consumers require products with higher internal quality. Therefore, addressing different aspects of internal quality, such as organoleptic and functional qualities, is a main objective. In this context, traditional varieties play an important role as potential germplasm for breeding programs given their well-known internal quality and their high variability.

\section{MATERIALS AND METHODS Vegetal Material}

A total of 51 entries of traditional varieties of tomato (Solanum lycopersicon), provided by the COMAV germplasm bank were studied (table 1). The seedbed was sown in April and was transplanted to a definitive field in May. 
The crop was conducted in a field located in Turis (Valencia, Spain). A randomized complete block design was used with four blocks, one plot per accession and 3 plants per plot. The crop was managed using the usual practices for tomato cultivation in the area including drip fertirrigation.

\section{Analytical Data}

1. Sample obtention and preparation. The fruits were harvested at the mature-red stage. Samples were composed of a mix of two representative fruits of each of the 12 plants per accession. In the laboratory, equivalent longitudinal portions for each fruit were obtained, They were ground and homogeneized. Samples were kept frozen at $-80^{\circ} \mathrm{C}$ until analysis.

2. Quantification of the soluble solids content. The soluble solids content (SSC) was estimated by refractometry of the juice (average of two determinations) using a digital refractometer (ATAGO PR-1, Tokyo, Japan) with $0,1^{\circ}$ Brix precission. The results were reported as ${ }^{\circ}$ Brix at $20^{\circ} \mathrm{C}$.

3. Sugar and acid quantification. A modification of the method described by Roselló et al., (2002) was used. This method is based on zone capillar electrophoresis and enables simultaneous quantification of oxalic, malic, glutamic, and citric acids and fructose, glucose, and sucrose sugars. A P/ACE MDQ capillar electrophoresis equipment was used for the analysis with the PA P/ACE MDQ Versión 2,3 software for Windows (Beckman Instruments Inc., Fullerton, CA. EE.UU.). A 50 $\mu \mathrm{m}$ internal diameter and $363 \mu \mathrm{m}$ external diameter capillar of melted silice (Polymicro Technologies, Phoenix, AZ., EE.UU.) with total length of $67 \mathrm{~cm}$ and $60 \mathrm{~cm}$ of effective length was used for the separations.

The concentration of each item was computed using linear regressions using 5 solutions with variable concentrations of each component. The determination coefficitent was larger than 0.99 in all cases. Each sample was analyzed twice. The results were reported in percentage of fresh weight $(\mathrm{g} / 100 \mathrm{~g}$ juice).

4. L-ascobic acid quantification. The method described by Galiana-Balaguer et al., (2001) was used. This protocol, based on capillary electrophoresis, uses a $50 \mu \mathrm{m}$ internal diameter and $363 \mu \mathrm{m}$ external diameter capillar of melted silice (Polymicro Technologies) with total length of $27 \mathrm{~cm}$ and $20 \mathrm{~cm}$ of effective length for the separations.

The concentration was computed using linear regressions using 5 solutions with variable concentrations of L-ascorbic acid. The coefficient of determination was larger than 0.99. Each sample was analyzed twice. The average of the values obtained in all blocks were reported. The results were expressed as $\mathrm{mg}$ per $100 \mathrm{~g}$ of fresh weight.

5. Lycopene quantification. The method reported by García-Plazaola and Becerril (1999) based on high performance liquid cromotography (HPLC) of reverse phase with stlight modifications was used. Analyses were carried out on a 1200 series cromatographer (Agilent Technologies, Santa Clara, US). The cromatography was conducted in a column of reverse phase Tracer Spherisorb ODS-1 (250 x $4.6 \mathrm{~mm}$ i.d., 5 $\mu \mathrm{m}$, particle size) protected by a guard column $(20 \mathrm{x} 3.9 \mathrm{~mm}$ i.d., $4 \mu \mathrm{m})$. The integration of the lycopene peaks was conducted at $470 \mathrm{~nm}$. Sudan I was used as internal standard. 
Lycopene concentration was obtained using linear regressions using 5 concentrations of known pattern. Always were obtained a $99.9 \%$ of coefficient of determination. Each sample was analyzed twice. The results were reported as ppm of fresh weight.

\section{RESULTS AND DISCUSSION}

Accession segregation was observed in several cases. Accession CDP8106, initially of pepper type, presented segregation. Although the pepper type (CDP8106(1)) was the main one, 4 plants of rounded morphotype (CDP8106(2)) were obtained. The accession CDP3947 also segregated generating 3 types: CD2226, with original morphotype, CDP1523 with round non-ribbed fruits, and CDP3947 with rounded ribbed fruits. This segregation is usual when working with original seeds, since farmers can provide mixed seeds or there may be a previous spontaneous hybridization and has been reviewed for other crops (Zeven, 2000).

A relevant content of oxalic acid was only obtained in four accessions: CDP7444, CDP6438, CDP3971(1) and CDP7499 (data not shown). This is a positive result since the oxalic acid is an antinutrient (Güil et al., 1996) and its relevance for total acidity and $\mathrm{pH}$ is almost negligible. The results obtained on oxalic acid content were smaller than those reported (around $35 \mathrm{mg} / 100 \mathrm{~g}$ ) for other traditional varieties (Cebolla Cornejo et al.. 2005).

Sucrose was only detected $(97,4 \mathrm{mg} / 100 \mathrm{~g})$ in accession CDP2714. The absence of sucrose accumulation is a standard feature of tomatoes given that the sucrose is hidrolized during the rippening process. However, sucrose traces have been obtained in some tomato varieties. In these, the concentration is always below $0.1 \%$ of fresh weight (Davies y Hobson, 1981), as in this case.

A large intervarietal variation for the remaining compounds was obtained. This variability was studied using principal component analysis. The oxalic and sucrose contents were not included considering their lack of variation. The two first components, which account for $70.5 \%$ of the total variation, were selected and plotted. The first component $(56.1 \%)$ was positively correlated with the content of all the evaluated variables. Therefore, the accessions with a large first component may be especially interesting. The second component (14.4\%) was positively correlated with the content of malic acid, glutamic acid, and fructose and negatively correlated with the content of citric acid, glucose and SSC.

The materials were irregularly distributed which made it difficult to identify specific groups (fig. 1). Out of this continuum of variation, only the accession CDP3547 was more isolated, with outstanding contents of most compounds.

In those few cases in which several accessions of the same variety were included (such as Moruno, Morado, Negro or Cuarenteno), they did not group themselves jointly. This seems to confirm the existence of a large intravarietal variability. It is not surprising that accessions of the same variety show different quality profiles given that traditional varieties are in fact population varieties. Nevertheless, the intravarietal evaluation is beyond the scope of this paper.

Since the 70s, researchers have focused on establishing correlations between analytical variables related with organoleptic quality and acceptability or preference order in tasting trials. There are several studies relating the content in soluble solids, total acidity, content in sugars, acids, and their relationships with acceptability or preference of some tomato varieties (Stevens, 1972; Stevens et al., 1979; Davies and Hobson, 1981; Jones and Scott, 1984; Malundo et al., 1995; Bucheli et al., 1999a). Koehler and Kays (1991) established the correlation between sugars and the sweetness. 
This relationship was also studied by other researchers (Baldwin et al., 1998; SalibaColombani et al., 1999). But the preference order in tasting trials seems to be more influenced by the relationship between sugars and acids than by the content in sugars (Baldwin et al., 1998). The highly valued samples were, however, those with higher sugar content as described by Malundo et al. (1995) and Bucheli et al. (1999a). Additionally, using traditional varieties the model that best captured the preference order of a tasting panel was one based on relating the content in sugars (measured as sucrose equivalents) and the sugars to citric acid ratio (ATC) (Cebolla-Cornejo, 2005). Considering all these relations, it would be interesting to detect the accessions standing out for their content in individual compounds, in order to combine them later in elite materials.

In this sense, the most relevant accessions considering their content in individual compounds (table 2) would be: accessions CDP3547 and CDP8102 because of their large content of malic acid (260.6 and $222.3 \mathrm{mg} / 100 \mathrm{~g}$ respectively), accession CDP6315 with a high content of citric acid (580.2 mg/100g), accession CDP9909 due to its low content of glutamic acid $(17 \mathrm{mg} / 100 \mathrm{~g})$, and accession CDP3547 because of its high content of fructose and glucose $(2,852.1$ and $1,733.0 \mathrm{mg} / 100 \mathrm{~g}$ respectively). For glutamic acid it is interesting to select accessions with lower values given that a higher sugar:glutamic ratio has been related to better acceptance in tasting trials (Bucheli et al., 1999b).

In terms of the content in compounds related with the functional quality (table 3 ), coefficients of variation (51.2\% for vitamin $\mathrm{C}$ and $74.6 \%$ for lycopene content) were higher than those affecting organoleptic quality (ranging from $18 \%$ for total soluble content to $38.8 \%$ for glutamic acid), showing a wide range of variation to identify sources of variation for breeding programmes. Accessions CDP1523 and CDP7554 should be highlighted for their high values in lycopene $(5.337$ and $4.493 \mathrm{mg} / 100 \mathrm{~g}$ PF respectively), doubling the standard content in tomato. The values of ascorbic acid were not particularly high, being the highest content $27.54 \mathrm{mg} / 100 \mathrm{~g}$ PF in accession CDP336. Nevertheless, it would be interesting to study the intravarietal variability and the stability of the content in accessions CDP2226 and CDP336.

In conclusion, the quality profiles of a considerably high representation of Spanish diversity of traditional tomatoes have been obtained. These profiles might be a key to lay down objectives in new breeding projects or to promote in situ conservation. The results obtained have shown that there is a significant intravarietal and intervarietal variability, enabling selections in both components.

\section{REFERENCES}

Baldwin, E.A., Scott, J.W., Einstein, M.A., Malundo, T.M.M., Carr, B.T., Shewfelt, R.L., Tandon, K.S. 1998. Relationship between sensory and instrumental analysis for tomato flavor. Journal of the American Society for Horticultural Science, 123 (5): 906915.

Bucheli, P., Lopez, J., Voirol, E., Petiard, V., Tanksley, S.D. 1999a. Definition of biochemical and molecular markers (quality trait loci) for tomato flavour as tools in breeding. Acta Horticulturae, 487: 301-306.

Bucheli, P., Voirol, E., Torre, R.R., Lopez, J., Rytz, A., Tanksley, S.D., Petiard, V. 1999b. Definition of nonvolatile markers for flavor of tomato (Lycopersicon esculentum Mill.) as tools in selection and breeding. Journal of Agricultural and Food Chemistry, 47 (2): 659-664. 
Cebolla-Cornejo, J., Roselló, S., Galiana-Balaguer, L., Nuez, F. 2005. Evaluación de la calidad organoléptica de variedades tradicionales de tomate y del efecto del cultivo bajo malla. Actas Portuguesas de Horticultura, 8: Volumen 4, 302-308.

Davies, J.N., Hobson, G.E. 1981. The constituents of tomato fruit - the influence of environment, nutrition, and genotype. CRC Critical Reviews in Food Science and Nutrition, 15 (3): 205-280.

Galiana Balaguer, L., Rosello, S., Herrero Martinez, J.M., Maquieira, A., Nuez, F. 2001. Determination of L-ascorbic acid in Lycopersicon fruits by capillary zone electrophoresis. Analytical Biochemisty, 296 (2): 218-224.

García-Plazaola, J.I., Becerril, J.M. 1999. A Rapid High-performance Liquid Chromatography Method to Measure Lipophilic Antioxidants in Stressed Plants: Simultaneous. Determination of Carotenoids and Tocopherols. Pytochemical Analysis, 10: 307-313,

Güil,J.L., Torija, M.E., Gimenez, J.J., Rodriguez-García, I., Giménez, A. 1996. Oxalic acid and calcium determination in wild edible plants. Journal of Agricultural and Food Chemistry, 44: 1821-1823.

Jones, R.A., Scott, S.J. 1984. Genetic potential to improve tomato flavor in commercial F1 hybrids. Journal of the American Society for Horticultural Science, 109 (3): 318-321.

Koehler, P.E., Kays, S.J. 1991. Sweet potato flavor: Quantitative and qualitative assessment of optimum sweetness. Journal of Food Quality, 14: 241-249.

Malundo, T.M.M., Shewfelt, R.L., Scott, J.W. 1995. Flavor quality of fresh tomato (Lycopersicon esculentum Mill.) as affected by sugar and acid levels. Postharvest Biology and Technology, 6 (1/2): 103-110.

Rosello, S., Galiana-Balaguer, L., Herrero-Martinez, J.M., Maquieira, A., Nuez, F. 2002. Simultaneous quantification of the main organic acids and carbohydrates involved in tomato flavour using capillary zone electrophoresis. Journal of the Science of Food and Agriculture, 82 (10): 1101-1106.

Saliba-Colombani, V., Causse, M., Philouze, J., Buret, M., Issanchou, S., Lesschaeve, I. 1999. QTLs for organoleptic quality in fresh market tomato. Genetics and breeding for crop quality and resistance Proceedings of the XV EUCARPIA Congress, Viterbo, Italy, September 20 25, 1998, 291-299 Registro 10 de 24 en Cab Abstracts 1998 : -299.

Stevens, A.M., Kader, A.A., Albright, M. 1979. Potential for increasing tomato flavor via increased sugar acid content. Journal of the American Society for Horticultural Science, 104 (1): 40-42.

Stevens, M.A. 1972. Citrate and malate concentrations in tomato fruits: genetic control and maturational effects. Journal of the American Society for Horticultural Science, 97 (5): 655-658.

Zeven, A.C. 2000. Traditional maintenance breeding of landraces:1. Data by crop. Euphytica 116: 65-85. 
Table 1. Origin and main characteristics of the accessions being evaluated

\section{ACCESSIONS LOCAL NAME}

CDP9909 Tomate del terreno

CDP9583 Tomate gordo del pais

CDP3001 Tomate del bueno

CDP3287 Tomate de pardo

CDP8473 Tomate caqui

CDP7635 Tomate de corazón $\quad$ Huelva

CDP5663 $\quad$ Tomate de San Pedro

CDP2666

CDP3600

CDP4551

CDP481

CDP6098

CDP276

CDP9696

CDP4237

CDP3947

CDP9352

CDP3604

CDP6169

CDP8106

CDP3480

CDP3547

CDP2714

CDP5540

CDP3250

CDP6315

CDP6043

CDP7554

CDP7596

CDP8237

CDP2498

CDP8443

CDP7718

CDP1819

CDP336

CDP4081

CDP8000

CDP77

CDP9005

CDP8737

CDP3971

CDP524

CDP6438

CDP9667

CDP7167

CDP7499

CDP720

CDP68

CDP7444

CDP8102

Tomate de Badajoz Tomate cherry

SITE OF

COLLECTION

Álava

Vizcaya

Vizcaya

Huesca

uelva

Almería

Almería

Almería

Granada

Tomate de pera;calabacita Málaga

Tomate forma pimiento Málaga

Tomate de pan Cádiz

Tomate de pera

Tomate morado

Tomate negrito

Tomate melillero

Córdoba

Tomate borondo

Tomate valenciano

Tomate pimiento largo

Tomate de Calzada

Tomate negro

Tomate criollo para mojo

Tomate de Monserrat

Tomate pometa

Tomate palo santo

Tomate rosa ple

Tomate montserrat

Tomate

Tomate cuarenteno

Tomate trunfera

Tomate moruno

Tomate casco duro

Tomate de pico

Tomate gordo rosa

Tomate rosa de colgar

Tomate

Tomate morado

Toledo moruno

Cáceres
Pontevedra

Ciudad Real

Ciudad Real

Tomate flor de baladre Murcia

Tomate de Guadalupe Murcia

Tomate muchamiel Murcia

Tomate del pais León

Tomate cuarenteno $\quad$ Valencia

Alicante

Tomate de San Juan

Tomate cuarenteno

Valencia

Valencia

$\begin{array}{ll}\text { Tomate valenciano } & \text { Valencia } \\ \text { Tomate raf } & \text { Alicante }\end{array}$

T. casero de Aretxabaleta Vizcaya

Tomate corazon de moreno Álava
FRUIT SHAPE

ASSIGNED

TYPE

Flattened intermediate ribbed

Flattened slightly ribbed

Flattened slightly ribbed

Flattened/rounded slightly ribbed

Flattened slightly ribbed

Strongly flattened strong ribbed

Flattened intermediate ribbed

Rounded slightly ribbed

Purple flattened absent ribbed

Flattened slightly ribbed

Pepper-shaped slightly ribbed

Pepper-shaped slightly ribbed

Cherry non-ribbed

Rounded/heart-shaped pink slightly ribbed

Strongly flattened strong ribbed

Flattened/rounded slightly ribbed

Heart-shaped/rounded slightly ribbed

Heart-shaped/rounded slightly ribbed

Heart-shaped/rounded slightly ribbed

Slightly flattened slightly ribbed

Pepper-shaped slightly ribbed

Flattened/rounded slightly ribbed

Flattened/rounded slightly ribbed

Flattened/rounded slightly ribbed

Strongly flattened pink strong ribbeb

Flattened slightly ribbed

Rounded slightly ribbed

Flattened slightly ribbed

Strongly flattened intermediate ribbed

Rounded pink slightly ribbed

Rounded slightly ribbed

Flattened/rounded very slightly ribbed

Flattened intermediate ribbed

Strong flattened slightly ribbed

Heart-shaped slightly ribbed

Slightly flattened slightly ribbed

Slightly flattened slightly ribbed

Heart-shaped slightly ribbed

Strongly flattened pink slightly ribbed

Strongly flattened strong ribbed

Strongly flattened strong ribbed

Flattened slightly ribbed

Flattened slightly ribbed

Rounded slightly ribbed

Flattened slightly ribbed

Flattened/ rounded intermediate ribbed

Heart-shaped/rounded slightly ribbed

Heart-shaped/rounded slightly ribbed

Strongly flattened intermediate ribbed

Strongly flattened slightly ribbed

Flattened/rounded intermediate ribbed

$\mathrm{A}$

A

$\mathrm{B}$

A

$\mathrm{D}$

E

F

$\mathrm{B}$
$\mathrm{A}$
$\mathrm{H}$

$\mathrm{H}$

$\mathrm{H}$

A

$\mathrm{F}$

$\mathrm{J}$

$\mathrm{H}$


Table 2. Accessions with the highest values in compounds related to organoleptic quality.

\begin{tabular}{|c|c|c|c|c|c|}
\hline $\begin{array}{c}\text { ACCESSION } \\
\text { S }\end{array}$ & $\begin{array}{l}\text { MALIC ACID } \\
(\mathrm{mg} / 100 \mathrm{~g} \text { FW) }\end{array}$ & ACCESSIONS & $\begin{array}{l}\text { CITRIC ACID } \\
\text { (mg/100g FW) }\end{array}$ & ACCESSIONS & $\begin{array}{l}\text { GLUTAMIC ACID } \\
\text { (mg/100g FW) }\end{array}$ \\
\hline A-CDP3547 & 277,31 & C-CDP6315 & 580,22 & A-CDP9909 & 17,00 \\
\hline A-CDP8102 & 260,59 & H-CDP3947(1) & 473,20 & C-CDP5663 & 46,92 \\
\hline B-CDP771 & 221,28 & B-CDP7444 & 462,12 & J-CDP8000 & 53,49 \\
\hline H-CDP3604 & 214,73 & A-CDP3547 & 450,54 & A-C-L-249 & 55,22 \\
\hline I-CDP7596 & 213,24 & H-CDP3947 & 446,11 & A-CDP6043 & 60,52 \\
\hline $\begin{array}{c}\text { ACCESSION } \\
\mathrm{S}\end{array}$ & $\begin{array}{c}\text { FRUCTOSE } \\
(\mathrm{mg} / 100 \mathrm{~g} \text { FW) }\end{array}$ & ACCESSIONS & $\underset{(\mathrm{mg} / 100 \mathrm{~g} \text { FW })}{\text { GLUCOSE }}$ & ACCESSIONS & SSC ( ${ }^{\circ}$ Brix) \\
\hline A-CDP3547 & 2852,05 & A-CDP3547 & 1723,02 & F-CDP4811 & 5,9 \\
\hline I-CDP7596 & 2482,24 & I-CDP7596 & 1335,46 & A-CDP3001 & 5,7 \\
\hline C-CDP6315 & 2454,24 & F-CDP4811 & 1251,59 & A-CDP336 & 5,7 \\
\hline $\mathrm{J}-\mathrm{CDP} 720$ & 2334,03 & H-CDP3947 & 1195,85 & B-CDP771 & 5,3 \\
\hline H-CDP3604 & 2285,81 & A-CDP336 & 1169,15 & H-CDP2226 & 5 \\
\hline
\end{tabular}

Table 3. Lycopene and ascorbic acid contents.

\begin{tabular}{|c|c|c|}
\hline \multirow{2}{*}{ ACCESSIONS } & \multirow{2}{*}{$\begin{array}{c}\text { LICOPENE } \\
(\mathrm{mg} / 100 \mathrm{~g} \mathrm{FW})\end{array}$} & \multirow{2}{*}{$\begin{array}{c}\text { ASCORBIC } \\
\text { ACID } \\
(\mathrm{mg} / 100 \mathrm{~g} \mathrm{FW})\end{array}$} \\
\hline & & \\
\hline CDP9909 & 2,158 & 6,83 \\
\hline CDP9583 & 0,602 & 21,69 \\
\hline CDP3001 & 2,518 & 21,39 \\
\hline CDP3287 & 1,351 & 22,17 \\
\hline CDP8473 & 2,179 & 0,96 \\
\hline CDP7635 & 1,456 & 17,31 \\
\hline CDP4688 & 1,578 & 0,39 \\
\hline CDP5663 & 2,465 & 20,91 \\
\hline CDP2666 & 0,620 & $\mathrm{n}, \mathrm{d}$ \\
\hline CDP3600 & 3,802 & 9,92 \\
\hline CDP4551 & 1,111 & 11,32 \\
\hline CDP4811 & 2,227 & 14,28 \\
\hline CDP6098 & 2,393 & 5,31 \\
\hline CDP276 & 0,394 & 7,04 \\
\hline CDP9696 & 0,855 & 15,51 \\
\hline CDP4237 & 1,099 & 13,45 \\
\hline CDP2226 & 1,780 & 26,67 \\
\hline CDP1523 & 5,337 & $\mathrm{n}, \mathrm{d}$ \\
\hline CDP3947 & 4,000 & 6,49 \\
\hline CDP9352 & 0,766 & 14,67 \\
\hline CDP3604 & 3,517 & 12,2 \\
\hline CDP6169 & 4,338 & 11,68 \\
\hline CDP8106(1) & 3,335 & 20,78 \\
\hline CDP8106(2) & 0,839 & 17,44 \\
\hline CDP3480 & 2,951 & $\mathrm{n}, \mathrm{d}$ \\
\hline CDP3547 & 0,432 & 0,94 \\
\hline CDP2714 & 3,584 & 8,14 \\
\hline
\end{tabular}

\begin{tabular}{ccc}
\hline \multirow{2}{*}{ ACCESSIONS } & LICOPENE & $\begin{array}{c}\text { ASCORBIC } \\
\text { ACID }\end{array}$ \\
\cline { 2 - 3 } & $\mathbf{( m g / \mathbf { 1 0 0 } \text { FW) }}$ & $\mathbf{( m g / 1 0 0 g} \mathbf{~ F W})$ \\
\hline CDP5540 & 0,530 & 16,62 \\
\hline CDP3250 & 1,654 & 16,72 \\
\hline CDP6315 & 1,506 & 19,49 \\
\hline CDP6043 & 1,456 & 15,51 \\
\hline CDP7554 & 4,493 & $\mathrm{n}, \mathrm{d}$ \\
\hline CDP2498 & 0,654 & 18,62 \\
\hline CDP7596 & 2,429 & 21,65 \\
\hline CDP8443 & 1,980 & $\mathrm{n}, \mathrm{d}$, \\
\hline CDP7718 & 1,987 & 23,31 \\
\hline CDP8237 & 1,905 & 12,56 \\
\hline CDP1819 & 4,184 & 15,01 \\
\hline CDP336 & 3,000 & 27,54 \\
\hline CDP4081 & 3,706 & 17,04 \\
\hline CDP8000 & 2,324 & 20,94 \\
\hline CDP771 & 1,627 & 17,54 \\
\hline CDP9005 & 1,547 & 19,97 \\
\hline CDP8737 & 0,478 & 22,38 \\
\hline CDP3971 & 1,413 & $\mathrm{n}, \mathrm{d}$, \\
\hline CDP524 & 2,349 & 5,53 \\
\hline CDP6438 & 2,110 & 0,71 \\
\hline CDP9667 & 1,665 & 12,95 \\
\hline CDP7167 & 3,089 & 6,32 \\
\hline CDP7499 & 2,175 & 8,84 \\
\hline CDP720 & 1,250 & 13,13 \\
\hline CDP68 & 2,224 & 3,89 \\
\hline CDP7444 & 0,647 & 9,55 \\
\hline CDP8102 & 0,768 & 8,68 \\
\hline & &
\end{tabular}


Figure 1. Principal components analysis considering compounds related to organoleptic quality

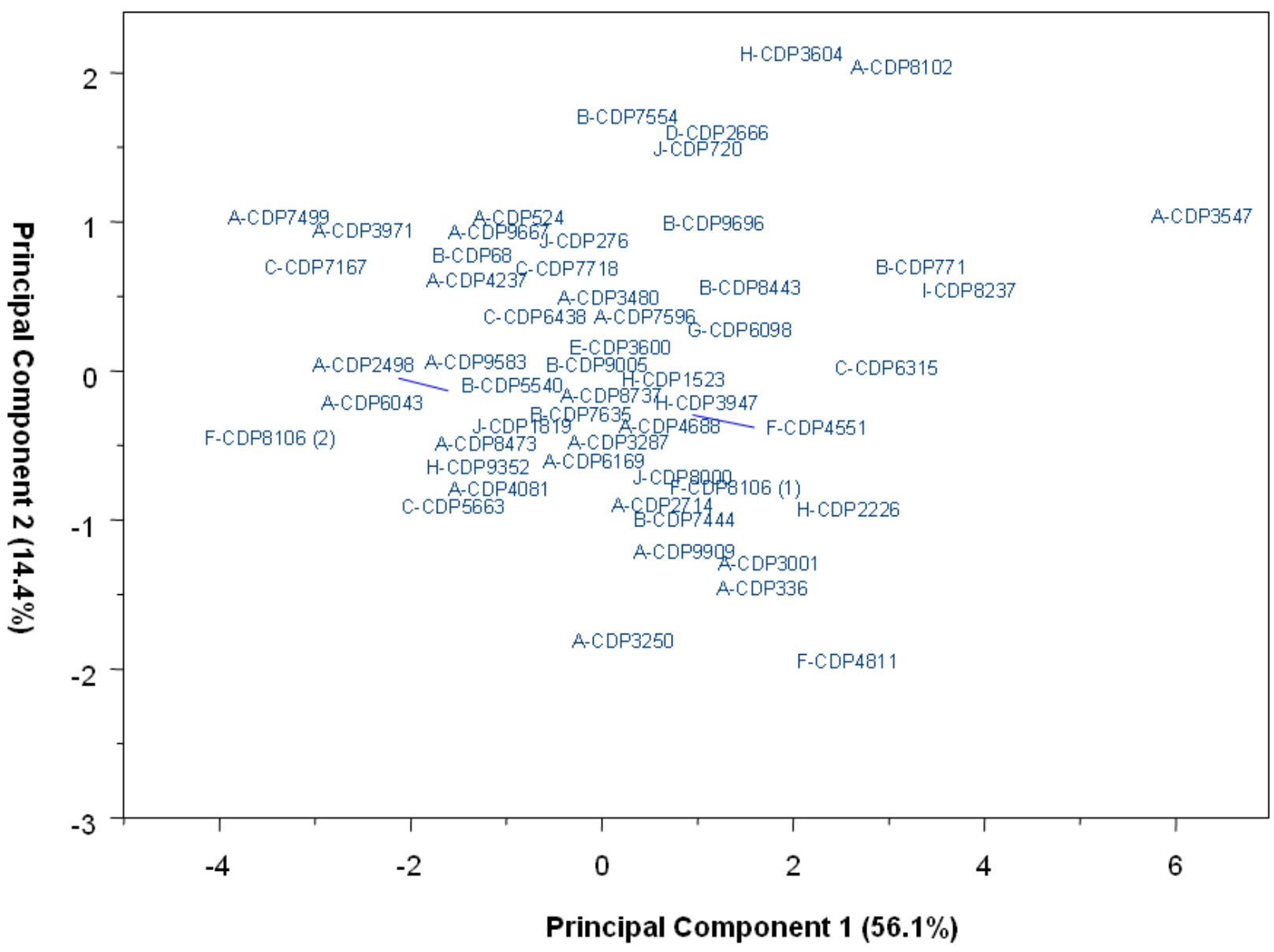

